\title{
Right to Treatment for the Civilly Committed: A New Eighth Amendment Basis
}

Although more than a decade has passed since the courts first considered the idea of a constitutional right to treatment for involuntarily committed mental patients, it remains unclear whether the civilly committed indeed have such a right. Prior to the Supreme Court's 1975 decision in O'Connor $v$. Donaldson, ${ }^{1}$ the lower federal courts had begun to fashion a due process right to treatment. ${ }^{2}$ In Donaldson, however, the Court avoided the question of whether the due process clause guarantees a right of treatment and, in a footnote, explicitly deprived of precedential value the appellate opinion below, which had recognized such a right. Since Donaldson, the lower courts have been understandably reluctant to rule on the question. Various arguments have also been advanced that the civilly committed can invoke the eighth amendment's prohibition of "cruel and unusual punishment," either to outlaw involuntary civil commitment to mental institutions or to monitor the conditions of such confinement. ${ }^{3}$ But while courts have suggested that involuntarily confined juveniles have an eighth amendment right to adequate treatment, ${ }^{4}$ no court has articulated a persuasive theory of eighth amendment applicability.

This comment will briefly review the caselaw and commentary on the right to treatment. It then will examine the Supreme Court's recent eighth amendment opinions in Ingraham $v$. Wright ${ }^{5}$ and

\footnotetext{
1422 U.S. 563 (1975).

2 See, e.g., Donaldson v. O'Connor, 493 F.2d 507 (5th Cir. 1974), vacated, 422 U.S. 563 (1975).

3 See, e.g., Developments in the Law-Civil Commitment of the Mentally Ill, 87 Harv. L. REv. 1190, 1330-33 (1974) [hereinafter cited as Developments]; Comment, Eighth Amendment Right to Treatment for Involuntarily Committed Mental Patients, 61 lowA L. REv. 1057 (1976); Note, Civil Restraint, Mental Illness, and the Right to Treatment, 77 Yale L.J. 87, 97-100 (1967).

- The eighth amendment has been employed in juvenile cases. In Martarella v. Kelly, 349 F. Supp. 575 (S.D.N.Y. 1972), for example, the court held that juveniles involuntarily committed to a New York state training system enjoyed a constitutional right to treatment. The source of the right was held to be a combination of the eighth amendment's restrictions on what can be punished, see Robinson v. California, 370 U.S. 660 (1962), discussed in text and notes at notes 33-40 infra, and the due process analysis of Wyatt v. Stickney, $344 \mathrm{~F}$. Supp. 387 (M.D. Ala. 1972), modified sub nom. Wyatt v. Aderholt, 503 F.2d 1305 (5th Cir. 1974). The court stated: "There can be no doubt that the right to treatment, generally, for those held in non-criminal custody . . . has by now been recognized by the Supreme Court." 349 F. Supp. at 599.
}

5430 U.S. 651 (1977). 
Estelle v. Gamble ${ }^{6}$ and argue that they lay the basis for eighth amendment scrutiny of the treatment of the civilly committed.

\section{Previous Arguments for a Right to Treatment}

\section{A. Fourteenth Amendment Due Process}

The idea that a civilly committed mental patient has a due process right to treatment ${ }^{7}$ was not broached judicially until Judge Bazelon discussed the issue in dictum in the 1966 case of Rouse $v$. Cameron. ${ }^{8}$ The habeas petitioner in that case had been confined following a criminal verdict of not guilty by reason of insanity and argued that the legality of his confinement should be conditioned on the state's provision of treatment. While the petitioner prevailed on statutory grounds, ${ }^{9}$ Judge Bazelon, in his opinion for the District of Columbia Circuit, speculated about the constitutionality of denying treatment to those in the petitioner's circumstances. The petitioner had at the time already been confined for four years, with no end in sight; he could have been confined for at most a year had he been found criminally responsible for the crime charged. ${ }^{10}$ Because petitioner's need for treatment was the cause of the prolongation of his confinement, Judge Bazelon thought that the failure to supply treatment raised a significant due process question."

Judge Bazelon's dictum bore fruit in the Fifth Circuit's decision in Donaldson v. O'Connor. ${ }^{12}$ In 1957 Kenneth Donaldson was civilly committed to a Florida state hospital for "care, maintenance, and treatment;"'13 until his release in 1971, however, he received only "custodial care." ${ }^{14}$ In Donaldson's action for damages under section

- 429 U.S. 97 (1976).

- Judicial consideration of the right to treatment question followed in the wake of much scholarly consideration. The seminal piece is usually considered to be Birnbaum, The Right to Treatment, 46 A.B.A.J. 499 (1960). Other representative works include Bassiouni, The Right of the Mentally Ill to Cure and Treatment: Medical Due Process, 15 DePaul L. Rev. 291 (1966); Katz, The Right to Treatment-An Enchanting Legal Fiction? 36 U. CHI. L. REv. 755 (1969); Developments, supra note 3, at 1316-58; Comment, Eighth Amendment Right to Treatment for Involuntarily Committed Mental Patients, supra note 3; Note, Civil Restraint, Mental Illness, and the Right to Treatment, supra note 3.

373 F.2d 451 (D.C. Cir. 1966).

D.C. CODE § 21-562 (1967) provides: "A person hospitalized in a public hospital for a mental illness shall, during his hospitalization, be entitled to medical and psychiatric care and treatment."

10 373 F.2d at 453.

1 Id.

${ }^{12} 493$ F.2d 507 (5th Cir. 1974), vacated, 422 U.S. 563 (1975).

${ }^{13} 422$ U.S. 563, 565-66 (1975).

14 Id. at 569. 
$1983,{ }^{15}$ the jury rendered a verdict against the director of the hospital. The Fifth Circuit affirmed, holding that a person "involuntarily civilly committed to a state mental hospital has a constitutional right to receive such individual treatment as will give him a reasonable opportunity to be cured or to improve his mental condition."16 Judge Wisdom, for the court, developed two rationales for a due process right to treatment. The first takes as a premise Professor Tribe's broad proposition that "any" nontrivial governmental abridgment of freedom must be justified in terms of some "permissible governmental goal."17 Applying that proposition to commitments where the state's purpose in committing a nondangerous person is to care for him (the parens patriae rationale), the court concluded that treatment must be provided because absent treatment the "'nature' of the commitment bears no 'reasonable relation' to its 'purpose" " and due process is therefore violated. ${ }^{18}$ The second rationale set forth applies regardless of the basis of the involuntary confinement. ${ }^{19}$ Drawing on a range of authority which it saw as establishing "that governments must afford a quid pro quo when they confine citizens in circumstances where the conventional limitations of the criminal process are inapplicable,"20 the court held that because of the absence of those limitations in civil commitment the government can justify confinement only by providing a quid pro quo in the form of rehabilitative treatment. ${ }^{21}$

is Donaldson's original suit, filed while he was still a patient, was brought as a class action on behalf of himself and the patients of an entire department of the hospital involved. In addition to damages, the complaint requested habeas corpus relief and declaratory and injunctive relief to secure treatment. Prior to trial, Donaldson was released and his class action complaint dismissed. His complaint was then amended to include only the claim for damages. Id. at $565 \mathrm{n} .1$.

1" 493 F.2d at 520.

"Id. (citing Tribe, Foreword-Toward a Model of Roles in the Due Process of Life and Law, 86 HARv. L. Rsv. 1, 17 (1973)).

in 493 F.2d at 521 (citing Jackson v. Indiana, 406 U.S. 715, 738 (1972) ("due process requires that the nature and duration of commitment bear some reasonable relation to the purposes for which the individual is committed")).

"In addition to the parens patriae rationale for civil commitment, the police power is used as a basis for the involuntary confinement of those found dangerous to themselves or to others. 493 F.2d at 520-21.

* Id. at 524. The three limitations are "that detention be in retribution for a specific offense; that it be limited to a fixed term; and that it be permitted after a proceeding where the fundamental procedural safeguards are observed." Id. at 522.

${ }^{21}$ Id. See also Wyatt v. Aderholt, 503 F.2d 1035, 1312 (5th Cir. 1974) ("where the justification [for civil commitment] was the danger to self or to others, then treatment [has] to be provided as the quid pro quo society had to pay as the price of the extra safety it derived from the denial of individuals' liberty"). The panel in Morales v. Turman, 562 F.2d 993, 997 (5th Cir. 1977), characterized treatment as "quid pro quo for reduced procedural protections." 
On certiorari, a unanimous Supreme Court vacated the appeals court's judgment. ${ }^{22}$ The Court avoided reaching the issue of right to treatment; the whole of the Court's opinion was devoted to the question of whether Donaldson could be committed at all consistently with due process, and not to questions concerning the permissible conditions of confinement. ${ }^{23}$ Finding sufficient evidence to support the jury's conclusions that Donaldson was not dangerous to himself or to others and that he was not receiving treatment, the Court held that Donaldson's "constitutional right to liberty" had been violated: "[A] State cannot constitutionally confine without more a nondangerous individual who is capable of surviving safely in freedom by himself or with the help of willing and responsible family members and friends." ${ }^{24}$ The judgment was vacated and the case remanded because the court of appeals failed to consider the propriety of the trial court's refusal to instruct the jury concerning the hospital superintendent's defense of good faith reliance on state law authorization..$^{25}$ In a footnote the Court pointedly instructed the appeals court to consider on remand only the issue of monetary liability, adding: "Of necessity our decision vacating the judgment of the Court of Appeals deprives that court's opinion of precedential effect, leaving this Court's opinion and judgment as the sole law of the case." 26 Chief Justice Burger, as if to bolster the authority of that footnote, devoted ten pages of his twelve page concurrence to the proposition that the Fifth Circuit's analysis regarding a right to treatment had "no basis in the decisions of this Court."27

${ }^{22}$ O'Connor v. Donaldson, 422 U.S. 463 (1975).

${ }^{23}$ Id. at 573. The Court also refused to decide

whether, when, or by what procedures, a mentally ill person may be confined by the State on any of the grounds which, under contemporary statutes, are generally advanced to justify involuntary confinement of such a person-to prevent injury to the public, to ensure his own survival or safety, or to alleviate or cure his illness.

Id. at 573.74 (footnote omitted). The jury had found none of those grounds for continued confinement present in Donaldson's case. Id.

24 Id. at 576.

25 Id. at 576-77.

${ }^{2 s}$ Id. at $577 \mathrm{n} .12$.

${ }^{27}$ Id. at 580-89. The concurrence runs from $578-89$.

Concerning the Fifth Circuit's first theory, the Chief Justice agreed that commitment must be justified by a "Iegitimate state interest" and that "confinement must cease when those reasons no longer exist." Id. at 580 . He disagreed, however, with the Court's assertion that Florida's only purpose in confining Donaldson was to provide him with treatment. The Fifth Circuit's finding of a right to treatment was defensible, he said, only if the states have "no power to confine the mentally ill except for the purpose of providing them with treatment." Id. at 581. This conclusion the Chief Justice found insupportable: "[T]he existence of some due process limitations on the parens patriae power does not justify the further conclusion that it may be exercised to confine a mentally ill person only if the purpose of the confinement is treatment." Id. at 583-84. The Fifth Circuit's quid pro quo theory of due 
The Court's stance in Donaldson-in particular its avoidance of the treatment issue and its apparent displeasure with the Fifth Circuit's opinion-seems to have deterred the lower courts from finding a due process right to treatment. In a recent case the Third Circuit remanded a case for further factual development rather than decide whether the involuntarily committed have a right to treatment. ${ }^{28}$ And the Fifth Circuit in Morales $v$. Turman, ${ }^{29}$ a case brought by juveniles challenging the adequacy of programs and conditions in youth detention facilities, characterized Judge Wisdom's quid pro quo theory as "questionable" and expressed doubt as to the existence of a due process right to treatment. ${ }^{30}$

\section{B. Past Eighth Amendment Arguments}

Some courts have suggested that treatment rights may be required by the eighth amendment. The first judicial support for eighth amendment arguments is, again, Judge Bazelon's opinion in Rouse $v$. Cameron. ${ }^{31}$ After noting the possible due process issues in the case, he suggested that "[i]ndefinite confinement without treatment of one who has been found not criminally responsible may be so inhumane as to be 'cruel and unusual punishment." "32 As support, Judge Bazelon cited the Supreme Court's decision in Robinson $v$. California, ${ }^{33}$ which held that the eighth amendment forbids a state to criminally punish a person for a mere status-in that case, the status of being a narcotics addict. Although the relevance of Robinson to the right to treatment issue does not readily reveal itself, a number of lower courts have found in Robinson a

process, Chief Justice Burger said, is a "sharp departure" from traditional due process analysis, in that it "would elevate a concern for essentially procedural safeguards into a new substantive constitutional right." Id. at 586-87. He saw no warrant for simply assuming that the civilly committed are denied adequate safeguards and on that basis imposing upon the state a duty to provide treatment as a form of compensation. Id. The Chief Justice also expressed skepticism about the wisdom of judicial involvement in regulating the provision of mental treatment in state mental institutions:

Given the present state of medical knowledge regarding abnormal human behavior and its treatment, few things would be more fraught with peril than to irrevocably condition a State's power to protect the mentally ill upon the providing of "such treatment as will give [them] a realistic opportunity to be cured."

Id. at 588-89.

2s Scott v. Plante, 532 F.2d 939 (3d Cir. 1976) (noting that the Fifth Circuit had decided the issue after a trial that developed the facts; Rule 12(b)(6) dismissal held improper).

25 562 F.2d 993 (5th Cir. 1977).

so Id. at 998.

31 373 F.2d 451 (D.C. Cir. 1966).

32 Id. at 453.

370 U.S. 660 (1962). 
basis for an eighth amendment right to treatment..$^{34}$ The theory is that civil commitment without treatment may visit upon confinees deprivations that are equivalent to criminal punishment, and that, absent treatment, the confinement therefore amounts to a punishment for the status of being mentally ill.

The commentators have, for various reasons, found the Robinson argument unpersuasive ${ }^{35}$ The most obvious difficulty with the argument is that the Court in Robinson approved in dictum the use of civil commitment as a legitimate response to narcotics addiction..$^{36}$ Another difficulty is that Robinson itself concerned only the question whether a person could be punished at all for a status-at base, a substantive due process question-and really had very little to do with the traditional concern of the eighth amendment, regulation of the manner and conditions of punishment. Finding a principled basis for using Robinson to regulate the conditions of civil commitment is therefore difficult. Furthermore, the extension requires a wholesale identification of civil commitment without treatment with the criminal justice system. ${ }^{37}$ Criminal con-

3 See, e.g., Welsch v. Likins, 373 F. Supp. 487, 496-97 (D. Minn. 1974) (semble); Martarella v. Kelley, 340 F. Supp. 575, 599-600 (S.D.N.Y. 1972) (juvenile detention of "persons in need of supervision"). See also Welsch v. Likins, 550 F.2d 1122, 1125 (8th Cir. 1977) (affirming a later order of the district court in Welsch and expressing approval of the lower court's constitutional analysis).

${ }^{3 s}$ See, e.g., Developments, supra.note 3, at 1330-31; Note, Civil Restraint, Mental Illness, and the Right to Treatment, supra note 3.

36 U.S. at 664-65. The Court stated: "In the interest of discouraging the violation of such laws or in the interest of the general health and welfare of its inhabitants, a State might establish a program of compulsory treatment or might require periods of involuntary confinement." Id. In Powell v. Texas, 392 U.S. 514 (1968), however, the Court seemed to retreat somewhat from the unqualified endorsement in Robinson:

[T] he medical profession cannot, and does not, tell us with any assurance that, even if the buildings, equipment and trained personnel were made available [for treating alcoholics], it could provide anything more than slightly higher-class jails for our indigent habitual inebriates. Thus we run the grave risk that nothing will be accomplished beyond the hanging of a new sign-reading "hospital"-over one wing of the jailhouse.

One virtue of the criminal process is, at least, that the duration of penal incarceration typically has some outside statutory limit. . . . "Therapeutic civil commitment" . . . lacks this feature; one is typically committed until one is "cured". Thus, to do otherwise than affirm might subject indigent alcoholics to the risk that they be locked up for an indefinite period of time under the same conditions as before, with no more hope than before of receiving effective treatment and no prospect of periodic "freedom." Id. at 529. See also Jackson v. Indiana, 406 U.S. 715, 737 \& n.23 (1972) (dictum) ("Considering the number of persons affected, it is perhaps remarkable that the substantive constitutional limitations on this power have not been more frequently litigated") (citing Powell and Robinson); O'Connor v. Donaldson, 422 U.S. 563, 588 n.9 (1975) (Burger, C.J., concurring).

${ }^{37}$ Although it is argued below, see text and notes at notes $90-95$, that the circumstances and surroundings of the civilly committed are very similar to the circumstances of incarcer- 
viction, however, involves moral reprobation not associated with civil commitment. And, as Justice Douglas pointed out in his concurring opinion in Robinson, it was this aspect of criminal punishment that provided strong support for the Court's holding that there are limits to the state's authority to declare certain kinds of conduct criminal. ${ }^{38} \mathrm{~A}$ final difficulty with the Robinson argument is that the argument, once extended, would be hard to contain: if commitment without treatment amounts to a punishment for status under Robinson, then it is hard to see why commitment with treatment is not also forbidden. This is particularly true of commitments grounded on the state's police power, where the rationale for the commitment is not to care for the committed person but rather to protect society by incarcerating him.

Perhaps as a consequence of these difficulties, the lower courts have apparently been somewhat unsure of themselves in extending Robinson: in the course of finding a constitutional right to treatment, they either cite Robinson without much explanation ${ }^{39}$ or simply use it to buttress the due process argument. ${ }^{40}$ In any event, the Robinson approach has not proven a solid basis for a constitutional right to treatment.

\section{ApPlicability of the Eighth AMENDMENT Outside the Criminal Context}

The development of a straightforward and persuasive eighth amendment basis for a right to treatment for the civilly committed has, until recently, seemed barred by the historical confinement of the amendment to the regulation of criminal punishment.41 The prohibition of "cruel and unusual punishments" appeared first in

ated criminals, civil commitment is not analogous to criminal punishment in the Robinson sense, because it is not imposed for retributive or deterrent purposes. See Developments, supra note 3, at 1331-33. But see Allen, Criminal Justice, Legal Values, and the Rehabilitative Ideal, 50 J. CRM. L.C. \& P.S. 226, 230 (1959).

370 U.S. at 676 ("Cruel and unusual punishment results not from confinement, but from convicting the addict of a crime . . . A prosecution for addiction, with its resulting stigma and irreparable damage to the . . . accused, cannot be justified as a means of protecting society, where a civil commitment would do so as well.").

3. See, e.g., United States v. Jackson, 306 F. Supp. 4, 6 (N.D. Cal. 1969); People v. Feagley, 14 Cal. 3d 338, 359, 535 P.2d 373, 386, 121 Cal. Rptr. 509, 522 (1975).

10 See, e.g., Welsch v. Likins, 373 F. Supp. 487, 496 (D. Minn. 1974); Martarella v. Kelley, 349 F. Supp. 575, 599-600 (S.D.N.Y. 1972).

"See Johnson v. Glick, 481 F.2d 1028, 1032 (2d Cir.) (Friendly, J.), cert. denied, 414 U.S. 1033 (1973) (expressing "considerable doubt that the cruel and unusual punishment clause is properly applicable at all until after conviction and sentence"). But see Furman v. Georgia, 408 U.S. 238, 316-18 (1972) (Marshall, J., concurring) (suggesting that the English prohibition may have been adopted partially in response to the use of torture to extract confessions from suspects). 
the British Declaration of Rights of $1689 .{ }^{42}$ Historians have since debated whether the clause was aimed at punishments unauthorized by statute or disproportionate to the offense, or at the cruel-though technically legal-sentences of the "Bloody Assizes." 43 In either case, the provision spoke primarily to the criminal process. Statements of the Founding Fathers on the need for such a provision as an adjunct to the new constitution similarly focused on limiting the state's power to deal with persons convicted of crime.4 Nevertheless, language in the Supreme Court's opinion in the "school paddling" case of Ingraham $v$. Wright $t^{45}$ gives reason for believing that the amendment may regulate conditions of noncriminal confinement as well.

In view of the history of the eighth amendment, as the Court observed in Ingraham, it should not be surprising that every Supreme Court decision prior to Ingraham concerning the "cruel and unusual punishment" clause involved a challenge to aspects of criminal-type punishment. ${ }^{46}$ In those decisions, however, the Court spoke of the flexibility of the eighth amendment's scope. The Court has often reiterated that "the words of the Amendment are not precise, and their scope is not static. The Amendment must draw its meaning from the evolving standards of decency that mark the progress of a maturing society." ${ }^{47}$ In Gregg $v$. Georgia,${ }^{48}$ for instance,

${ }^{12}$ See 1 W. \& M. 2, c. 2 (1689). See generally Granucci, "Nor Cruel and Unusual Punishments Inflicted": The Original Meaning, 57 CALIF. L. REv. 839 (1969); see also Ingraham v. Wright, 430 U.S. 651, 664-67 (1977); Gregg v. Georgia, 428 U.S. 153, 168-73 (1976) (plurality opinion); Furman v. Georgia, 408 U.S. 238, 316-28 (Marshall, J., concurring) (history of cruel and unusual punishments clause).

${ }^{43}$ See Ingraham v. Wright, 430 U.S. 651, 664-65; Granucci, supra note 42 at 852-60.

"See Furman v. Georgia, 408 U.S. 238, 319-21 (1972) (Marshall, J., concurring).

15430 U.S. 651 (1977).

ss Id. at 666-67 (citing Estelle v. Gamble, 429 U.S. 97 (1976) (incarceration without medical care); Gregg v. Georgia, 428 U.S. 153 (1976) (execution for murder); Furman v. Georgia, 408 U.S. 238 (1972) (execution for murder); Powell v. Texas, 392 U.S. 514 (1968) (\$20 fine for public drunkenness); Robinson v. California, 370 U.S. 660 (1962) (incarceration as a criminal for addiction to narcotics); Trop v. Dulles, 356 U.S. 86 (1958) (expatriation for desertion); Louisiana ex rel. Francis v. Resweber, 329 U.S. 459 (1947) (execution by electrocution after a failed first attempt); Weems v. United States, 217 U.S. 349 (1910) (15 years' imprisonment and other penalties for falsifying an official document); Howard v. Fleming, 191 U.S. 126 (1903) (10 years' imprisonment for conspiracy to defraud); In re Kemmler, 136 U.S. 436 (1890) (execution by electrocution); Wilkerson v. Utah, 99 U.S. 130 (1879) (execution by firing squad); Pervear v. Commonwealth, 72 U.S. (5 Wall.) 475 (1867) (fine and imprisonment at hard labor for bootlegging)).

${ }^{37}$ Trop v. Dulles, 356 U.S. 86, 100-01 (1957) (holding that denationalization as a punishment is barred by the eighth amendment; though denationalization involves no physical mistreatment or torture, it is nevertheless "primitive" because "it destroys for the individual the political existence that was centuries in the development"). See also Gregg v. Georgia, 428 U.S. 153, 171, 172 (1976) (the prohibition of "cruel and unusual punishments" is not "fastened to the obsolete but may acquire meaning as public opinion becomes enlightened 
Mr. Justice Stewart, for the Court plurality, remarked that "an assessment of contemporary values concerning the infliction of a challenged sanction is relevant to the application of the Eighth Amendment." ${ }_{49}$

Relying on such statements, the plaintiffs in the Ingraham case tried to escape the historical pattern that has confined the amendment to the criminal context. As junior high school students they had been paddled so severely for disciplinary infractions that they suffered hematoma and other injuries requiring medical attention..$^{50}$ In an action for monetary, injunctive, and declaratory relief under the Civil Rights Acts, they asked the courts to liken the beatings they had suffered to the beatings that "hardened criminals" might suffer at the hands of jailers, ${ }^{51}$ conduct that presumably would raise a valid claim under the eighth amendment. ${ }^{52}$

The Supreme Court's careful response to this argument suggests that the protections of the eighth amendment might extend to civilly committed mental patients. Though it reviewed the full history of Supreme Court eighth amendment adjudication and decided to adhere to the long-standing limitation on its applicability, ${ }^{53}$ the Court did not reject the plaintiffs' analogy out of hand. Rather, it acknowledged that "this logic may have [force] in other settings." 54 Elaborating this point in footnote 37, the majority speculated that

by a humane justice") (citing Weems v. United States, 217 U.S. 349, 373 (1910)); Robinson v. California, 370 U.S. 660, 666 (1962) ("[I]n light of contemporary human knowledge, a law which made a criminal offense of . . . a disease [like mental illness, leprosy, or venereal diseases] would doubtless be cruel and unusual punishment").

4* 428 U.S. 153 (1976).

19 Id. at 173. The plurality opinion argued that such an assessment is not made by a subjective judgment but rather by a survey of "objective indicia that reflect the public attitude toward a given sanction." Id.

so Ingraham v. Wright, 430 U.S. 651,657 (1977).

51 Id. at 668-69.

${ }^{52}$ Id. But cf. Johnson v. Glick, 481 F.2d 1028, 1031 (2d Cir.), cert. denied, 414 U.S. 1033 (1973) (Friendly, J.) ("The great weight of authority in favor of the assumption [that brutal police conduct violates a right guaranteed by the due process clause of the fourteenth amendment] has not been accompanied by an equivalent amount of analysis.")

ss 430 U.S. at 664-66. In arguing that the eighth amendment has always been limited to the criminal context, the Court cited Uphaus v. Wyman, 360 U.S. 72 (1959), where the Court rejected an eighth amendment challenge to an incarceration for civil contempt for refusal to comply with a subpoena. 430 U.S. at 668 . The circumstances of those incarcerated for civil contempt can be distinguished from the circumstances of civilly committed mental patients, however, by focusing on the fact, noted by the Court in Uphaus, that persons jailed for civil contempt "carry the keys to freedom," 360 U.S. at 81 , for they will be released as soon as they decide to conform to the court's order.

51 Id. at 669 (footnote omitted). Despite this acknowledgment and its elaboration in footnote 37 of the opinion, the Court in footnote 40 asserted that 
[s]ome punishments, though not labeled "criminal" by the state, may be sufficiently analogous to criminal punishments in the circumstances in which they are administered to justify application of the Eighth Amendment. . . . We have no occasion in this case, for example, to consider whether or under what circumstances persons involuntarily confined in mental or juvenile institutions can claim the protection of the Eighth Amendment. ${ }^{55}$

The majority proceeded to reject the plaintiffs' analogy by carefully comparing the contexts in which the two kinds of punishments are administered, concluding that the schoolchild and the prisoner "stand in wholly different circumstances." the "harsh facts of criminal conviction and incarceration." 57 The former allows the state to stigmatize the inmate by classifying him as a criminal and to deprive him of his liberty. ${ }^{58}$ The brutality a prisoner experiences can be seen as part of the total punishment for his crime; bringing it within the eighth amendment prohibition of punishments that are "unnecessary and wanton infliction[s] of pain." 59 In contrast, the schoolchild is not really confined, though attendance at school might be mandatory. He goes home every night and, unless very young, is physically free to go home even during the day. The support of family and friends can thus reach into the school, providing community supervision and safeguards against abuse. ${ }^{60}$ Where the schools remain open, criminal law sanc-

Eighth Amendment scrutiny is appropriate only after the State has complied with the constitutional guaranties traditionally associated with criminal proceedings . . . The State does not acquire the power to punish with which the Eighth Amendment is concerned until after it has secured a formal adjudication of guilt in accordance with due process of law. When the State seeks to impose punishment without such an adjudication, the pertinent constitutional guarantee is the Due Process Clause of the Fourteenth Amendment.

430 U.S. at $671-72$, n.40. The Court did not explore, or even mention, the possible implications of this proposition for footnote 37's suggestion that the eighth amendment may apply in some non-criminal settings. But the two footnotes may be reconcilable. After all, many of the "constitutional guarantees traditionally associated with criminal prosecutions" are applicable in the civil commitment context. See cases cited note 80 infra. All that footnote 40 may mean in the context of civil commitment is that the eighth amendment is not available as a ground for challenging the procedures involved in the commitment proceeding; on this reading, footnote 40 stands as no bar to eighth amendment applicability once a person has been committed pursuant to an adjudication of dangerousness or mental incompetency.

ss 430 U.S. at 669 n.37 (emphasis supplied).

${ }^{56} I d$. at 669.

IId. $\because$.

.5x Id.

s9. Id at 669-70.

so Id. at 670 . 
tions and common law remedies for excessive force can effectively deter and punish the infliction of harsh discipline and can adequately compensate the victim. The majority saw the schoolchild as therefore having "little need" for the protection from abuse afforded prisoners by the eighth amendment. ${ }^{\text {.1 }}$

Footnote 37 and the surrounding discussion of the schoolchild's circumstances suggest two requisites for applying the eighth amendment beyond the criminal justice context. First, there must be a punishment, and second, the punishment must be "sufficiently analogous" to criminal punishments in the context in which it is administered. Ingraham is not very helpful in specifying the sorts of acts that might qualify as "punishment" beyond the strictly criminal setting. The majority seemed to concede that severe paddling for breaking school rules can be seen as a "punishment." 62 The Ingraham plaintiffs failed, however, because they were unable to satisfy the second criterion-the analogy to a criminal's circumstances. The opinion is instructive as to the most important features of those circumstances.

The Court began by mentioning the harshest facts of the inmate's condition: the deprivation of freedom and the stigmatization that criminal conviction entails. The more crucial of the two is perhaps the inmate's involuntary confinement. This, more than any other factor, renders the prisoner helpless and in need of protection. $\mathrm{He}$ is at the state's mercy for the necessities of life and health. Should he be abused, he is little able to protect himself or remedy the occurrence. Nor is he likely to receive effective aid from the outside community, family, or friends. It was essentially the lack of any real confinement that distinguished the schoolchild's need for eighth amendment protection from the criminal's need. All of the other factors mentioned by the Court to differentiate the school situation-support of family and friends, presence of adult witnesses who might protest untoward paddlings, community supervision, availability of state civil and criminal sanctions for disciplinary abuse-are largely the incidents of the child's freedom. Those factors effectively protect the child only because the children and their parents are relatively free to move in and out of the school building environment.

On this score the confinement of the involuntarily committed mental patient is virtually identical to that of the prisoner. The massive loss of liberty, accompanied by regimentation, separation

"Id.

(2) Id. at $668-70 \&$ n.39. 
from loved ones, and dependence on others for the satisfaction of basic needs, renders the civilly committed, like prisoners, nearly helpless. ${ }^{63}$ And as the District of Columbia Circuit noted in In re Ballay, "the loss of liberty - the interest of 'transcending value" "may be even greater in the case of the civilly committed because commitment statutes sometimes provide for indefinite commitment. ${ }^{64}$

The other major characteristic of criminal punishments is stigmatization. ${ }^{65}$ Although commentators have suggested that the eighth amendment is concerned only with the "particular stigma" attached to criminal punishments, ${ }^{66}$ there seems to be no persuasive reason why this should be so. Given the suggestion in footnote 37 in Ingraham that the circumstances of mistreatment need not be identical to the circumstances of criminal punishment, but only "sufficiently analogous," in order to trigger the applicability of the eighth amendment, the definite stigma still associated with mental illness in our society becomes a second powerful point of analogy to the criminal context. Although criminal conviction, unlike civil commitment, may carry implications about moral worth, ${ }^{67}$ the effects of the two stigmas are nevertheless similar: society reacts to the label by ostracizing the marked person and by placing certain disabilities on him..$^{88}$

63 See In re Ballay, 482 F.2d 648, 669 (D.C. Cir. 1973).

os Id. at 668 (quoting Speiser v. Randall, 357 U.S. 513, 525 (1958)). Ballay also cited Professor Allen's warning: "[M]easures which subject individuals to the substantial and in. voluntary deprivation of their liberty are essentially punitive in character, and this reality is not altered by the facts that the motivations that prompt incarceration are to provide therapy or otherwise contribute to the person's well-being or reform." Id. at 667 (emphasis in original), (quoting Allen, Criminal Justice, Legal Values and the Rehabilitative Ideal, supra note 3, at 230 (1959)). See also United States ex rel. Stachulak v. Coughlin, 520 F.2d 931, 936 n.5 (7th Cir. 1975) (commitment under the Illinois Sexually Dangerous Persons Act is "an alternative to a criminal prosecution [and thus] in a very real sense a penal measure"). Cf. In re Winship, 397 U.S. 358, 365-66 (1970) ("civil labels and good intentions do not themselves obviate the need for criminal due process safeguards in juvenile courts").

${ }^{25}$ It is not easy to give specific content to a concept whose prime referent is a social response. Non-legal definitions are not limited to the idea of criminal blame:

stigma . . . 1. A mark made with a burning iron, formerly upon criminals, slaves, etc.; a brand. 2. Any mark of infamy or disgrace; a sign of moral blemish; stain or reproach caused by dishonorable conduct. 3. A mark or sign of blemish, defect, taint, or the like. Webster's New International Dictionary of the English Language (2d ed. 1935).

"Developments, supra note 3 , at 1333.

${ }_{67}$ The legal system allows an insanity defense in recognition of the belief that a person must be in some sense responsible for his behavior before society can justly blame him for his anti-social actions. See generally Livermore \& Meehl, The Virtues of M'Naughten, 51 Minn. L. REv. 789 (1967).

6x See In re Ballay, 482 F.2d 648, 667-69 (D.C. Cir. 1973); Justin v. Jacobs, 449 F.2d 1017, 1019-20 (D.C. Cir. 1971). 
The criminal stigma is a means by which society vents its feelings of disapproval and revulsion at the criminal's antisocial acts. ${ }^{69}$ In recognition of the social and legal consequences that flow from the stigma, courts have given criminal convicts rights to challenge their convictions even after they have served their sentences. ${ }^{70}$ The stigma associated with civil commitment or with a formal finding of mental illness or incompetence has similarly debilitating consequences. In addition to the obvious social consequences, ${ }^{71}$ many legal disabilities often flow from the label. One whose record shows a commitment for mental illness may face "constitutional and statutory restrictions on his voting rights; restrictions on his right to serve on a federal jury; restrictions on his ability to obtain a driver's license; and limitations on his access to a gun license."72 Because an adjudication of mental incompetency often gives rise to a rebuttable presumption of continued incompetency, ${ }^{73}$ such persons might encounter obstacles to the effective execution of wills and contracts or to the effective disposition of property. ${ }^{74}$ In addition, evidence of a prior commitment may be instrumental in a later commitment proceeding..$^{75}$ Consideration of this array of lasting disabilities has led courts to conclude, against claims of mootness, that persons can challenge the procedures under which they were civilly committed after they have been released. ${ }^{76}$ The persistent and severe character

" See, e.g., discussions of the expressive function of criminal punishment in J. FEINBERG, Doing and Deserving 98, 100-05, 115-16 (1970); 2 J. Stephen, A History of the Criminal LAW IN ENGLAND 81-82 (1883).

${ }^{70}$ In Fiswick v. United States, 329 U.S. 211 (1946), for instance, an alien who had been convicted of conspiring to defraud the United States in the exercise of its governmental functions (by concealing his membership in the Nazi party) and who had served his sentence was granted appellate review of his conviction. The Supreme Court held that Fiswick had a "substantial stake" in the judgment of conviction that survived execution of the sentence: his conviction could be used against him in deportation hearings and moreover, would force him to "carry through life the disability of a felon," thereby losing certain civil rights such as the rights to serve on a jury, vote, and hold state office. Id. at 222. See also Carafas v. LaVallee, 391 U.S. 234, 237-38 (1967) (petition for habeas corpus maintainable though petitioner was unconditionally released prior to resolution because of the "collateral consequences" attendant upon conviction, including, in addition to those listed in Fiswick, disability to engage in certain businesses or to serve as an official of a labor union for a specified period of time); Note, Civil Disabilities of Felons, 53 VA. L. REv, 403 (1967).

"See generally In re Ballay, 482 F.2d 648, 668 n.72 (D.C. Cir. 1973); B. EnNis, Prisoners of Psychiatry: Mental Patients, Psychiatrists and the Law 145-78 (1972).

72 In re Ballay, 482 F.2d 648, 651-52 (D.C. Cir. 1973).

is See, e.g., Hurt v. United States, 327 F.2d 978, 981 (8th Cir. 1964); Meteoris v. United States, 108 F.2d 402, 405 (7th Cir. 1939).

"In re Ballay, 482 F.2d 648, 652 (D.C. Cir. 1973).

${ }^{75}$ See, e.g., Covington v. Harris, 419 F.2d 617, 626-27 (D.C. Cir. 1969); Brown v. United States, 375 F.2d 310, 318 (D.C. Cir. 1966), cert. denied, 388 U.S. 915 (1967).

is In re Ballay, 482 F.2d 648, 651-53 (D.C. Cir. 1973). See also Justin v. Jacobs, 449 F.2d 1017, 1019-20 (D.C. Cir. 1971); Suzuki v. Quisenberry, 411 F. Supp. 1113, 1134-35 (D. Hawaii 1976). 
of the stigma associated with involuntary civil commitment is thus very similar to that of the criminal stigma. In In re Ballay ${ }^{77}$ Judge Tamm compared the severity of the two kinds of stigma: "Even accepting recent medical advances, current studies clearly indicate the fallacy of contending that most people view mental illness as a disease similar to any physical ailment of the body."78

Review of the two factors that seemed to be the most important to the Ingraham Court-confinement and stigma-thus demonstrates that the civilly committed are in circumstances quite analogous to those of criminal confinees ${ }^{79}$ and that they need eighth amendment protection just as much. ${ }^{80}$ If the Ingraham criteria are taken to define the limits of the eighth amendment's reach, then the

${ }^{n} 482$ F.2d 648 (D.C. Cir. 1973).

7x Id. at 668 .

73 The analogy holds for most of the other, lesser factors the Ingraham Court considered in comparing the context of criminal punishment and school discipline. For example, one comparison of institutional regulations and conditions in a state prison with those in a state mental health facility revealed that the hospital's rules were more restrictive than the prison's in almost every respect. J. Katz, J. Goldstein \& A. Dershowttz, Psychoanalysis, Psychiatry AND THE LAW 701-02 (1967), reproduced in United States ex rel. Schuster v. Herold, 410 F.2d 1071, 1090-91 (2d. Cir.), cert. denied, 396 U.S. 847 (1969). See E. Gorfman, Asylums 1-124 (1961). Similarly, community involvement in supervision of mental institutions is not likely to be any greater than that of prisons. See Visotsky, Adequacy of Treatment and Provisions for Methods of Assuring Adequacy of Treatment, in The Mentally Ill and the Right to TREATMENT 65 (G. Morris ed. 1970). ("The citizenry, relieved of their responsibility to the mentally ill by [the transformation, as a result of the work of Dorothea Dix] of the mental hospital into a large, isolated, centralized institution, found it easy to forget about their existence and were able to settle into apathetic indifference."); M. ScHWARTZ \& C. SCHWARTZ, Social Approaches to Mental Patient Care 136-37 (1964).

so Courts have in the past found that a combination of confinement and stigma justifies the application of some criminal law standards outside the criminal justice system. In re Winship, 397 U.S. 358, 365-67 (1970) (reasonable doubt standard applicable to juvenile proceedings adjudicatory in nature); In re Gault, 387 U.S. 1, $20-24$ (1967) (due process clause applicable to juvenile proceedings adjudicatory in nature where commitment to state institution may follow); United States ex rel. Stachulak v. Coughlin, 520 F.2d 931, 935-36 (7th Cir. 1975) (reasonable doubt standard applicable to commitment proceedings under the Illinois Sexually Dangerous Persons Act, ILL. REv. STAT., ch. 38, \& 105-1.01 (1975)); In re Ballay, 482 F.2d 648, 668-69 (D.C. Cir. 1973) (reasonable doubt standard applicable to civil commitment); Suzuki v. Quisenberry, 411 F. Supp. 1113, 1132 (D. Hawaii 1976) (same); $c$. Stamus v. Leonhardt, 414 F. Supp. 439, 449 (S.D. Iowa 1976) (clear and convincing evidence in civil commitment proceedings); Lynch v. Baxley, 386 F. Supp. 378, 393 (M.D. Ala. 1974) (same).

In the wake of Donaldson courts and commentators have increasingly concluded that a finding of dangerousness should be a prerequisite for civil commitment. See Comment, Overt Dangerous Behavior as a Constitutional Requirement for Involuntary Commitment of the Mentally Ill, 44 U. CHI. L. REv. 562 (1977), and cases cited therein. This trend underscores the need of persons civilly committed for eighth amendment protection; as has been noted, "if the dangerously mentally ill have no constitutional right to receive treatment and if they may be confined as long as they remain dangerous, there there would appear to be no practical or legal remedy for the deprivation of their liberty." Grant, Donaldson, Dangerousness, and the Right to Treatment, 3 Hastings Const. L.Q. 599, 610 (1976). 
foregoing analysis strongly suggests that the committed should enjoy whatever protections are provided by the amendments prohibition of "cruel and unusual punishment."

\section{The Application of the Eighth Amendment to the Treatment of THE Crvilly CommitTed}

Once it is granted that the circumstances of civil commitment are sufficiently analogous to the circumstances of criminal incarceration that the eighth amendment governs the treatment of the civilly committed, the scope of the protection thus afforded must still be determined. Estelle v. Gamble, ${ }^{82}$ a recent Supreme Court decision regarding prisoners' eighth amendment rights to medical treatment, provides a starting point for this inquiry.

\section{A. Estelle v. Gamble: Deliberate Indifference to Serious Medical Needs as Punishment}

J.W. Gamble, an inmate of the Texas Department of Corrections, was injured while performing a prison work assignment. Though he was seen by prison doctors and other medical personnel at least seventeen times, he brought a section 1983 suit alleging that the treatment he received had been inadequate. The Supreme Court read the handwritten pro se complaint as charging that the prison doctors and administrators had subjected him to cruel and unusual punishment in violation of the eighth amendment, made applicable to the states by the fourteenth. ${ }^{83}$ Noting that the eighth amendment proscribes "more than physically barbarous punishments," the Court stated that the amendment embodies "broad and idealistic concepts of dignity, civilized standards, humanity, and decency." ${ }^{84}$

"I This is not to say that civil commitment is equivalent to criminal punishment for all purposes. Were that the case, Robinson v. California, 370 U.S. 660 (1962), would appear to prohibit civil commitment altogether because such commitment would constitute a punishment for the status of being mentally ill. See text and notes at notes 36-40 supra. The Court in Ingraham did not discuss the relevance of the various factors it considered as indicia of eighth amendment applicability-principally, confinement and stigma-in order to determine whether school paddling is a "punishment." Indeed the Court admitted that paddling constitutes punishment. The Court focused instead on whether the punishment could be analogized to criminal punishment given the nature of the circumstances in which the pain was inflicted. Similarly, the argument here relies not on a finding that civil commitment is a punishment-for in most cases it is not, since it is not imposed for retributive or deterrent purposes-but rather on the analogous circumstances involved whenever state action (or inaction) affects civilly committed persons in a manner that would be "cruel and unusual punishment" if the same action affected a prisoner.

*2 429 U.S. 97 (1976).

* Id. at 101 .

* Id. at 102 (citing Jackson v. Bishop, 404 F.2d 571, 579 (8th Cir. 1968) (Blackmun, J.)). 
In the past, the Court noted, penal measures that were "incompatible with 'the evolving standards of decency that mark the progress of a maturing society," "85 or that " involve[d] the unnecessary and wanton infliction of pain" "s6 had been held to violate the amendment. The Court then asserted that "[t]hese elementary principles establish the government's obligation to provide medical care for those whom it is punishing by incarceration." 87 The argument was simple. Because a prisoner is confined, he is unable to meet his medical needs; if the authorities do not provide treatment, he will not get it. Consequences of a failure to treat might be severe: the prisoner might suffer the very physical "torture or lingering death" that the Framers meant to prohibit in drafting the eighth amendment. ${ }^{88}$ Short of this, the denial of care might cause pain and suffering that serves no penological purpose. ${ }^{89}$ Because the "infliction of such unnecessary suffering" is inconsistent with contemporary standards of decency, ${ }^{90}$ as evidenced by recent state legislation providing for inmate medical care and the teaching of the common law that "[i]t is but just that the public be required to care for the prisoner, who cannot, by reason of the deprivation of his liberty, care for himself," "91 the Court concluded that deliberate indifference to serious medical needs of prisoners constitutes the "unnecessary and wanton infliction of pain" prohibited by the eighth amendment. ${ }^{92}$

The Court, however, took care to distinguish "deliberate indifference" from merely negligent treatment, holding that the latter does not provide the basis for an eighth amendment claim because it does not constitute wanton infliction of unnecessary pain: "Medical malpractice does not become a constitutional violation merely because the victim is a prisoner." ${ }_{93}$ Reviewing the record in light of this distinction, the Court found that because Gamble had been examined frequently by the prison medical staff, his claim against the doctors was in the negligence category at best. The case was remanded for consideration of whether a cause of action had been stated against the other prison officials. ${ }^{94}$

429 U.S. at_102, (citing Trop v. Dulles, 356 U.S. 86, 101 (1958)).

so 429 U.S. at 103 (citing Gregg v. Georgia, 428 U.S. 153, 173 (1976) (joint opinion)).

$x 729$ U.S. at 103.

s* Id.

* Id.

so Id.

"Id. at 104 (citing Spicer v. Williams, 191 N.C. 487, 490, 132 S.E. 291, 293 (1926)).

82429 U.S. at 104.

$\$$ Id. at 106.

"Id. at 108. "The Court of Appeals focused primarily on the alleged actions of the doctors, and did not separately consider whether the allegations against the Director of the 


\section{B. A Right to Adequate Mental Treatment?}

Although the implementation of rights to psychiatric care may raise problems not confronted in implementing rights to adequate medical care for the body, it takes no great leap to see the implications of Gamble for a right to psychiatric treatment. Mental illness, like physical illness, occasions pain and suffering in the afflicted. The refusal to treat, in combination with the state's conduct in confining the individual in a manner that prevents him from getting any help on his own, therefore amounts to the infliction or aggravation of pain and suffering.

At least one court of appeals case supports this extension of Gamble. In Bowring $v$. Godwin, ${ }^{95}$ a state prisoner whose parole had been denied, in part because a psychological examination indicated he could not successfully complete a parole period, petitioned for habeas corpus relief on the ground that the prison had refused him the psychiatric treatment that would render him eligible for parole. The Fourth Circuit reversed a lower court determination that no constitutional claim had been presented. Noting that "constitutional doctrine" has absorbed the common law view that the public must provide care for the prisoner who cannot care for himself due to his incarceration, the court cited Estelle v. Gamble for the proposition that federal courts may require the states to provide "reasonable medical care, as needed." The court saw "no underlying distinction between the right to medical care for physical ills and its psychological or psychiatric counterpart." ${ }_{97}$

It might be objected that there is an important distinction between medical and psychiatric treatment. Failure to treat a wound or other serious physical ailment can lead to a progressive worsening of the condition. It is easy to see how deprivation of treatment-inaction-can be characterized as an infliction of pain in such circumstances. Where the patient suffers in a "steady state,"

Department of Corrections, Estelle, and the warden of the prison, Husbands, stated a cause of action." Id. On remand, the Fifth Circuit found that Gamble's complaint did not state a cause of action against the Director and warden. 554 F.2d 653 (5th Cir. 1977).

is 551 F.2d 44 (4th Cir. 1977), noted in 56 N.C.L. Rev. 612 (1978).

9s Id. at 46-47. In addition to Gamble's rule that failure to provide treatment through deliberate indifference inflicts the unnecessary and wanton pain proscribed by the eighth amendment, the court stated that such conduct also violates the fourteenth amendment due process clause since failure to treat could result in deprivation of life. Id. at 47.

"Id. at 47. The court supported its conclusion by noting that the Fifth Circuit had considered the lack of psychological care in testing the constitutionality of "systemwide conditions of confinement" and had held that the omissions of the Alabama penal system violated both the eighth and fourteenth amendments. Id. (citing Newman v. Alabama, 503 F.2d 1320 (5th Cir. 1974), cert. denied, 421 U.S. 948 (1975)). 
on the other hand, as may be the case with mental illness, and the public is asked to intervene for the purpose of improving his condition, it is not so easy to call the denial of treatment an infliction of pain. The simple answer is that Gamble did not differentiate between these two types of suffering. ${ }^{98}$ The Court's theory was that, had he been outside prison, Gamble could have sought treatment on his own. ${ }^{99}$ Confinement deprived him of that option, thus prolonging-that is, inflicting-the pain in a fashion that served no penological purpose. Such infliction of "wanton and unnecessary" suffering brings the eighth amendment prohibition of cruel and unusual punishments into-operation. The relevant inquiry-regardless of whether the condition in issue is mental or medical, constant or worsening-is whether there has been deliberate indifference to the treatable suffering of those whom the state has rendered helpless in a manner that implicates eighth amendment concerns.

\section{The Right to Mental Treatment for the Civilly Committed}

Although deliberate indifference to the serious psychiatric needs of a prison inmate may violate the eighth amendment, and although Ingraham suggests the applicability of the "cruel and unusual punishment" clause of the eighth amendment to the civil commitment context, it does not necessarily follow that the amendment forbids gross neglect of the needs of the civilly committed. Footnote 37 of the Court's Ingraham opinion says that certain punishments "may be sufficiently analogous to criminal punishments in the circumstances in which they are administered to justify application of the Eighth Amendment:" ${ }^{100}$ If the denial of treatment to a criminal confined in prison can violate the eighth amendment, it might seem that denial of treatment to a person civilly committed would also violate the amendment. But despite the similarity of the two official acts and despite the identical effects of the acts upon the two types of confinees, an argument can be made that official neglect in the civil commitment context has about it no aspects of punishment and therefore does not fall within the scope of the amendment's prohibitions.

9" Although the Court did point out that lack of treatment can lead to "torture or lingering death," it also suggested that denial of medical care in "less serious cases" would lead to pain that serves no penological purpose. The infliction of this "unnecessary suffering" violates the eighth amendment. 429 U.S. at 103.

99 See text and note at note 91 supra.

${ }^{100} 430$. U.S. at 669 n.37. 
The eighth amendment, in terms, prohibits not cruel and unusual treatment, but cruel and unusual punishment. Thus it would be natural to expect that the courts would apply the prohibition only to state action that is punitive in nature. The issue is seldom controversial in the typical eighth amendment case. ${ }^{101}$ Where a prisoner challenges a mode of execution, ${ }^{102}$ the length of a sentence, ${ }^{103}$ or prison conditions in general, ${ }^{104}$ he is clearly challenging the manner of his punishment. Ordinarily, state action is characterized as punitive if it is visited upon an individual in response to the individual's antecedent conduct in violation of an official norm. The sanction is imposed for the purposes of retribution or deterrence. Denial of treatment to the civilly committed does not fit this mold. If the eighth amendment only prohibits conduct that is punitive, then it is doubtful that the grossest neglect of the psychiatric needs of the civilly committed violates the amendment.

Moreover, nothing in the Ingraham case suggests that all official behavior towards the civilly committed comes within the purview of the eighth amendment. The case itself did not raise the punishment issue; there is no question that school paddling is punitive. The Court's discussion of the dissimilarity between the circumstances of schoolchildren and prisoners does not necessarily imply that the amendment's prohibition applies to all forms of official behavior towards individuals situated in circumstances sufficiently analogous to criminal confinement. Nor does footnote 37 suggest anything contrary to the view that the amendment prohibits only egregious punishments. The footnote speaks of "punishments" that are "analogous to criminal punishments in the circumstances in which they are administered," 105 suggesting perhaps that the amendment applies only to punitive measures imposed on a confinee for violating a rule of the institution or for violently misbehaving towards a nurse or proctor.

The difficulty with this argument against an eighth amendment "right to treatment" is that the Court in Gamble found nonpunitive official behavior to be cruel and unusual punishment. In Gamble the deprivation of medical care was not a quid pro quo for

${ }^{10 t}$ But see Trop v. Dulles, 356 U.S. 86 (1958), in which the success of a wartime deserter's eighth amendment challenge to the deprivation of his United States citizenship turned largely on the question of whether the sanction was punitive.

102 E.g., Furman v. Georgia, 408 U.S. 238 (1972).

${ }^{105}$ E.g., Weems v. United States, 217 U.S. 349 (1910).

tot E.g., Pugh v. Locke, 406 F. Supp. 318 (M.D. Ala. 1976), aff'd in part, 559 F.2d 283 (5th Cir. 1977).

ros 430 U.S. at 669 n.37. 
any misbehavior on the part of the plaintiff. There was no argument that the failure to treat was the result of a decision by warden or doctor to impose added punishment on Gamble for the act that originally brought him to prison. Nor was the failure to treat imposed as a punishment for in-prison rule infractions. Indeed, the Court emphasized that deliberate indifference to medical needs violates the eighth amendment because it serves no penological purpose. ${ }^{106}$

It could also be argued that deliberate indifference to Gamble's serious medical needs triggered the amendment's prohibition because the indifference transformed Gamble's punitive incarceration into cruel and unusual punishment. ${ }^{107}$ If "deliberate indifference" violates the eighth amendment only to the extent that it "taints" an already punitive incarceration, then deliberate indifference to the needs of the civilly committed is no violation. This is a questionable reading of Gamble, however, for the Court there focused on the refusal of medical treatment to Gamble individually, not on the nature of Gamble's confinement. ${ }^{108}$ Moreover, the argument is hardly persuasive in view of the strong suggestion in Ingraham that the eighth amendment regulates the treatment of persons in circumstances sufficiently similar to the conditions of criminal confinement. ${ }^{109}$ And finally, the argument relies on a literalness in interpreting the cruel and unusual punishment clause that seems at variance with the Court's flexible approach to defining the scope of the eighth amendment. ${ }^{110}$ If the amendment protects a prisoner such as Gamble from deliberate neglect because the state's act of confining him deprives him of the freedom to care for himself, there is no reason, aside from history, for denying similar protection to the civilly committed. If the eighth amendment serves the general purpose of regulating the state's treatment of those whom it holds at its mercy, then behavior that violates the eighth amendment in the

${ }^{106} 429$ U.S. at 102.

${ }^{107}$ Some support for this view can be drawn from dicta in the Supreme Court majority opinion in Ingraham. The Court cited, with seeming approval, the observation of the court of appeals below, that prison brutality is "'part of the total punishment to which the individual is being subjected for his crime and, as such, is a proper subject for Eighth Amendment scrutiny." 430 U.S. at 669 (quoting Ingraham v. Wright, 525 F.2d 909, 915 (5th Cir. 1976) (en banc)). In a parenthetical the Court characterized Gamble as a case about "incarceration without medical care." 430 U.S. at 666.

${ }_{108}$ The Court in Gamble did not address the threshold "punishment" issue at all, but concluded quite easily that the cruel and unusual punishments clause imposes on the government the obligation "to provide medical care for those whom it is punishing by incarceration." 429 U.S. at 103.

${ }^{109}$ See text and notes at notes 54-56 supra.

1ro See text and notes at notes 47-49, 84-92 supra. 
criminal justice context should be constitutionally prohibited in the civil commitment area as well.

\section{Administrative Concerns}

Although the Gamble and Ingraham opinions can be read to support an eighth amendment right to treatment for the civilly committed, it might seem that such an eighth amendment argument is open to the practical objections that Chief Justice Burger, in his Donaldson concurrence, levelled against the notion of a due process right to treatment. ${ }^{111}$ The Chief Justice was concerned that the recognition of a right to "such treatment as will give [the inmate] a realistic opportunity to be cured"'112 would involve the federal courts in issues beyond their competence-as the Chief Justice noted, the notions of "treatment," "cure," and, indeed, of illness itself are extremely ill-defined ${ }^{113}$-and would throw mental hospitalization systems into complete disarray. The objections are substantial, and, although the points were articulated by the Chief Justice only, the Court's testy footnote instructions to the court of appeals perhaps suggest that the Chief Justice's misgivings were shared by other members of the Court. Examination of an eighth amendment basis for treatment rights might be a futile exercise if the eighth amendment standard shares all the practical infirmities of Judge Wisdom's due process standard.

'1" The Chief Justice, citing Szasz, The Right to Health, 57 Geo. L.J. 734 (1969), stated that "there is considerable debate concerning the threshold questions of what constitutes 'mental disease' and 'treatment.' " 422 U.S. at 584 n.5 (Burger, C.J., concurring). He might have cited as well to the work of R.D. Laing, who would perhaps find many cures or treatments to be "cruel and unusual." See generally R.D. Laing, The Politics of Experience (1968).

112 This was the standard adopted by the Fifth Circuit below. Donaldson v. O'Connor, 497 F.2d 507 (5th Cir. 1974). Judge Wisdom, the author of the Fifth Circuit's opinion, has consistently maintained that judicial manageability problems are not insurmountable. In Wyatt v. Aderholt, 503 F.2d 1305 (5th Cir. 1974), he reiterated his belief that "the judiciary [is] competent to determine, at least in individual cases, whether psychiatric treatment was medically or constitutionally adequate." Id. at 1314 . The thought is that, conceding the difficulty of articulating standards, courts can nevertheless recognize inadequate treatment when they see it. See also Bazelon, Implementing the Right to Treatment, 36 U. CH. L. REv. 742 (1969). As expressed by one district court in a case involving the rights of juvenile confinees to treatment:

In undertaking its task, the court views its role not to be that of ultimate purveyor of standards of treatment. Rather, it sees itself as a guiding force in an evolutionary process. By specifically declaring certain practices to be unconstitutional, the court is attempting to furnish parameters for those administering the juvenile justice system, but such parameters are not inflexible.

Pena v. New York State Division for Youth, 419 F. Supp. 203, 207 (S.D.N.Y. 1976). 113422 U.S. at $584 \&$ n.5. 
Gamble's "deliberate indifference" standard, however, should not raise serious problems of administrability. The standard, after all, is not terribly exacting; it should require of administrators little more than competence and decency, or, as Judge Bazelon expressed it in the Rouse case, a "bona fide effort" to improve the lot of the civilly committed. ${ }^{114}$ That many of the mentally ill are untreatable ${ }^{115}$ or refuse to acknowledge their illness ${ }^{116}$ is beside the point. If the state exhausts all known therapies without avail, or fails to treat patients who refuse treatment, no claim of "deliberate indifference" can be sustained. That mere confinement- "milieu therapy"-may be the best "therapy" for many patients ${ }^{117}$ is no objection to eighth amendment scrutiny, but seems rather to suggest that judicial regulation of the conditions of civil confinement may prove relatively unobtrusive.

\section{CONCLUSION}

This comment has presented the case for an eighth amendment right to treatment based on the Supreme Court's recent opinions in Ingraham v. Wright and Estelle v. Gamble. The comment has argued that the reasoning of those cases can be extended to forbid deliberate indifference to the treatment needs of the civilly committed. While this conclusion does not follow syllogistically from Gamble and Ingraham-Gamble could be read as requiring minimal care for prisoners only, and Ingraham could be viewed as reaffirming the traditional limitations on the eighth amendment's applicability-the Court's opinions give promise of a solid constitutional basis for treatment rights.

Thomas D. Roberts

14 Rouse v. Cameron, 373 F.2d 451, 456 (D.C. Cir. 1966).

its See O'Connor v. Donaldson, 422 U.S. 563, 584 (Burger, C.J., concurring).

115 Id.

"17 "[S]ome mental patients respond, as do persons suffering from a variety of psychological ailments, to what is loosely called 'milieu treatment,' i.e., keeping them comfortable, well nourished, and in a protected environment." Id. at 578 n.2 (Burger, C.J., concurring). 